\title{
THE HOMILETIC PROFILE OF FATHER SOFIAN BOGHIU (1912-2002) - COMMEMORATING 15 YEARS SINCE HIS REPOSE IN THE LORD
}

\author{
Ph.D. Nicuşor BELDIMAN \\ Faculty of Orthodox Theology \\ "Justinian Patriarch" - University of Bucharest, \\ ROMÂNIA, \\ E-mail: prnbeldiman@gmail.com
}

\begin{abstract}
A remarkable spiritual personality, unanimously acknowledged, the archimandrite father Sofian was known and appreciated especially for three qualities or gifts that God had bestowed upon him: as a worthy church painter, preacher and chanter with a divine calling. His rare kindness, his modesty, his composure, his endless patience and his theological culture are features that make up his spiritual portrait. The homiletic activity conducted by the archimandrite father produced a volume entitled Collected Speeches. Sermons and Meditations, which includes together many of the sermons and meditations through which Father Sofian fervently preached the Savior's Gospel and its embodiments in the lives of Christians. His sermons have a regular form, and consist of three parts - the introduction, usually very short, intended to present the topic to the audience, followed by the body of the sermon which covers several pages, and the conclusion, which often includes an exhortation based on teachings extracted from the respective sermon. The three composing parts are not separated formally, but rather they derive naturally from one another.
\end{abstract}

Keywords: father Sofian; Collected Speeches; Sermons and Meditations; Antim Monastery; sermons;

\section{PRELIMINARY REMARKS}

Among the spiritual fathers who have enlightened the spirit of the Romanian people and have kept it in the true faith, like kindled candles, in an age when the forces of darkness worked diabolically to estrange it from God, father Sofian Boghiu ${ }^{1}$ has a well-deserved

\footnotetext{
${ }^{1}$ He was born on November7th, 1912 in Bassarabia, Cuconeştii-Vechi village, Bălţi County. At the age of 14 he joined the monastery Rughi-Soroca, between the years 1928-1932 he attended Church singers' School at the monastery of Dobruşa-Soroca, then the monastic Seminary at the Cernica Monastery (1932-1940). On December $25^{\text {th }}, 1937$ he was tonsured to join monastic life, changing his name from Serghie to Sofian, and on August 6th, 1939 he was ordained a deacon at the Cathedral in Bălţi by Metropolitan Bishop Tit Simedrea. He attended the Fine Arts Academy in Bucharest between the years 1940-1945, as well as the Faculty of Theology in Bucharest (1942-1946), obtaining a degree in theology with the thesis entitled Chipul Mântuitorului în iconografie (The Savior's Image in Iconography). In 1945 he was ordained a priest at the Antim monastery in Bucharest, taking part in the meetings of the Rugul Aprins (Burning Bush) between the years 1945-1948. On June $15^{\text {th }}, 1950$ he was appointed abbot of the Antim Monastery, and between the years 1954-1958 he led the monastic community at the Plumbuita Monastery. In 1958 he was arrested and imprisoned for "plotting", and sentenced to 16 years' forced labor, but released after the general amnesty in 1964. In 1967 he returned as
} 
place, having sustained for almost six decades, the spiritual life of the Antim Monastery in Bucharest, as its abbot, chaplain, preacher and servant of this holy place of worship. A remarkable spiritual personality, unanimously acknowledged, the archimandrite father Sofian was known and appreciated especially for three qualities or gifts that God had bestowed upon him: as a worthy church painter, preacher and chanter with a divine calling. We could also add to this moral portrayal his singular meekness, his modesty and calm, his boundless patience and his rich theological culture accumulated in time ${ }^{2}$.

As His Beatitude Patriarch Daniel asserted, father Sofian:

\begin{abstract}
"was the torch that revived souls, especially during the harsh years of the communist regime. He stretched out his arms to embrace the despondent people, giving reassurance to those whose hope failed, imparting light and guidance upon those prey to confusion, bringing revivifying freshness and joy to the lives of those who followed his fatherly advice. Through his life and service, as priest and preacher, chaplain and shepherd, celebrant and painter, he was a reflection of the Great Shepherd, instilling in his deeds the virtues of the service of Christ: humbleness, gentleness, wisdom, but, above all, love for God and for human beings",
\end{abstract}

Convinced that redemption can be attained only by complete commitment to faith, even to the utmost sacrifice, the archimandrite father immersed himself in the process of reinvigorating the spiritual life of the Christians through sermons, meditations, religious lectures, catechesis, and by intensifying the liturgical program. Having a sound theological background, as well as the qualities of a chaplain, he was sought not only by the simple Christians "but also by those belonging to the contemporary cultural and intellectual elite, evincing a great ability to respond to the problems and challenges of the times in which he lived" 4 .

abbot of the Antim Monastery and after an eventful course of 90 years of life he passed away on September $14^{\text {th }}, 2002$. He wrote many books and articles: Pictura murală şi iconografia neobizantină $̂$ in Biserica Ortodoxă Română (Mural painting and Neo-Byzantine Iconography in the Romanian Orthodox Church), in ,M.B.”, year XXXVI (1986), no. 3, pp. 49-57; Rugul Aprins şi temniţa (the Burning Bush and the Prison), in ,Vestitorul Ortodoxiei”, year VIII, no. 157, 15 June 1996; Dialoguri despre rugăciune (Dialogues on Prayer), in „Vestitorul Ortodoxiei”, year IX, no. 172, 15 January 1997; Ne vorbeşte Părintele Sofian (Father Sofian speaks to us), Publishing House of Sihăstria Monastery, Vânători-Neamţ, 1997; Taina Spovedaniei ca eveniment în viaţa Bisericii astăzi (The Mystery of Confession as an event in today's Church life), in ,Vestitorul Ortodoxiei”, year X, no. 198-199, February-March 1998; Cea mai desăvârşită pace este pacea lumii (The most perfect peace is the peace of the world), in „Vestitorul Ortodoxiei”, year XII, no. 239-240, 15 January 2000; Mitropolitul Antim Ivireanu (The Metropolitan Bishop Antim Ivireanul), in „B.O.R.”, year XXXXVI (2000), no. 7-12, pp. 306-334; Chipul Mântuitorului în iconografie (The Savior's Image depicted in Iconography), The Byzantine Publishing House of Bucharest, 2001; Smerenia şi dragostea, însuşirile trăirii creştine (Humbleness and love, the qualities of Christian living), Bucharest, 2001; Sfântul Antim Ivireanul şi Mănăstirea Tuturor Sfinţilor (Saint Antim Ivireanul lof Iberia and the Monatery of All Saints), Byzantine Publishing House, Bucharest, 2005

2 Archim. Ioanichie Bălan, Convorbiri duhovniceşti (Spiritual Conversations), vol. I, Editura Episcopiei Romanului şi Huşilor, 1993, p. 408.

3 † Daniel, Patriarch of the Romanian Orthodox Church, „Cuvânt înainte” (Foreword), in Un iconar de suflete - Părintele Sofian Boghiu (A painter of souls - Father Sofian Boghiu), Archim. Mihail Stanciu and Protos. Veniamin Goreanu (eds.), Basilica Publishing House of the Romanian Patriarchate, Bucharest, 2009, p. 7.

${ }^{4}$ Protos. Veniamin Goreanu, “,Vrednicul slujitor al lui Hristos, părintele Archimandrit Sofian Boghiu (The worthy servant of Christ, father archimandrite Sofian Boghiu (1912-2002)", in vol. Un iconar de suflete Părintele Sofian Boghiu (A painter of souls - Father Sofian Boghiu), Archim. Mihail Stanciu and protos. dr. Veniamin Goreanu (eds.), Basilica Publishing House, Bucharest, 2009, p. 48. 
The sermons delivered in the Iberian church were met with great interest and pleasure by the audience. With his warm, soft voice the father managed to captivate the listeners of all walks of life, because his speech was easily understood by all attendants.

\section{VOLUMES OF SERMONS}

The homiletic activity of the archimandrite father materialized in the volume entitled Buchet de cuvântări. Predici şi meditaţii (Collected speeches. Sermons and Meditations) ${ }^{5}$, which brings together some of the sermons and meditations through which "father Sofian tirelessly and arduously preached the Gospel of our Savior Jesus Christ and its experience in the life of the Righteous Church"6.

On reading the 40 sermons collected in this volume -2 exegetic homilies, 25 thematic sermons and 13 panegyrics - we easily realize 'the amount of time and spiritual effort which the Archimandrite Father Sofian put in his work in order to come to grasp the profound meanings meant to restore the soul of the teachings of the Holy Gospel of our Lord Jesus Christ"'?.

Some of the sermons have explanatory titles illustrating the theme: Despre Sfânta Impărtăşanie (On the Holy Communion), Praznicul Schimbării la Faţă (the Feast of the Transfiguration), Despre desăvârşire (On Perfection), Despre păzirea poruncilor (On Keeping the Commandments), Providenţa divină (On the Divine Providence), Despre Judecata particulara (On the particular judgment), Despre iertare şi impăcare (On forgiveness and reconciliation), Despre apostolate (On apostleship), Despre suferinţă (On suffering) or Sfătuire către cei ce se spovedesc (Advise to those who confess). We can find several sermons for the same liturgical day, while some sermons for certain Sundays and holidays are missing. At times, the titles of the sermons are reiterated because they were delivered for the same Sunday, but the nuances added by father Sofian from one sermon to the next are quite visible.

\section{SOURCES USED}

Even at the first glance it can be noticed that the sermons of the archimandrite father show careful labor in elaborating and explaining the themes, with frequent resort to the Holy Scripture, the Holy Fathers (Saint John Chrysostom, Saint Basil the Great, Saint Gregory the Great, Saint Cyril of Jerusalem, the Paterikon), the religious books (The Triodion, The Pentecostarion), at the same time introducing original and unique formulation. Additionally, we note the fact that the author also turns to the universal literature by referring to: Cicero, Voltaire, Lamartine, Newton, Tyndall and Kepler.

What impresses us in all these speeches is the powerful experience of the actual and effective presence of God in the Church, in those who overcome their own weaknesses; such is the sermon for the commemoration of Venerable Mother Paraskevi, the saint who, as a child, attended the church and heard the words of the Holy Gospel "If any man will come after me, let him deny himself, and take up his cross daily, and follow me" (Luke 9, 23), thus deciding to dedicate her life to our Savior, leading the harsh existence of a hermit, nourishing herself with prayer, guiding herself according to the words of the Saint Apostle Paul: "I discipline my body and make it my slave; so that, after I have preached to others, I

\footnotetext{
${ }^{5}$ EIBMBOR, Bucharest, 2006, 288 p.

${ }^{6} \dagger$ Teoctist, ,Precuvântare” (Preliminary Speech), to Archim. Sofian Boghiu, Buchet de cuvântări. Predici şi meditaţii (Collected Speeches. Sermons and meditations), EIBMBOR, Bucharest, 2006, p. 5.

7 †Teoctist, „Precuvântare (Preliminary Speech)...”, p. 5.
} 
myself will not be disqualified" (I Corinthians 9, 27). Praising the holy life of the Venerable Mother, father Sofian asserts:

\begin{abstract}
"The Holy Paraskevi, thus spiritually prepared, incessantly praising God for the comfort she experienced to the fullest, in all her solitude and poverty, started from there towards Jerusalem. With the Lord's aid she reached the destination of her journey. With great devotion she bowed before the Holy Sepulcher and before all the sacred places that had once been connected to the lives of the Savior and of the Lord's Mother" ${ }^{\prime 8}$. He presents her to us as a model of holiness, worthy of being followed: "A paragon of sacred zeal, a paragon of faith in God and kindness towards people and a paragon of steadiness in doing good is for us Saint Paraskevi, she who is of most help to us, those who seek her aid with confidence" 9 .
\end{abstract}

\title{
3. STRUCTURE
}

The sermons of the Archimandrite Sofian have a common form, consisting of three parts - the introduction, usually very short, meant to inform the listeners about the theme that is going to be discussed, followed by the body, covering many pages, and the ending, which most of the times includes an exhortation based on the teachings extracted from the respective sermon. The three parts that constitute the sermon are not indicated by particular forms of address, but they follow one another naturally. A case in point is the speech delivered on the occasion of the feast of the Lord's Transfiguration, which begins as follows:

"Every year, on August $6^{\text {th }}$, we celebrate one of the greatest Christian holidays - the Lord's Transfiguration on Mount Tabor. This Feast is truly great because there, on Mount Tabor, the Savior Himself revealed, as in a flashlight, His Godly Glory before the Apostles. Until such time, the Holy Apostles had only witnessed in awe His wonders, which were great and powerful signs of His godliness. But in their souls they considered the Savior still a man - a great prophet, the greatest sent by God amidst humans of all times. Yet, the events on Mount Tabor on the occasion of the Transfiguration, made the Holy Apostles comprehend that their great Teacher was not only a godly man, but the True God. What they witnessed experienced by on Mount Tabor will never be forgotten. Chronologically, this event occurred in the Savior's final year on earth, just a few months before His crucifixion" ${ }^{10}$. Other times, the introduction renders the feeling of a story continued before our eyes: "Great events had changed the world. One hundred years had passed since the eternal God, He who had made all things, was incarnate and born in the Bethlehem of Judea. One hundred years had passed since the Christian era had begun for mankind..."11.

In some sermons, the author organizes the body of his sermon based on various questions to which he provides the answers: "But can we ask ourselves: - What meaning does this even have for the Saint Apostles and for us? - What does the Savior teach us, people of today, through this event?"12 We often find in this approach an explanation of the word of the Scripture by means of a model that is logically structured, revealing how much father Sofian Boghiu cared for order, as is the case of the sermon on the Sunday of John of the Ladder:

\footnotetext{
${ }^{8}$ Archim. Sofian Boghiu, „Pomenirea Sfintei Cuvioase Parascheva” (Commemoration of the Venerable Saint Paraskevi), in vol. Buchet de cuvântări...(Collected speeches), p. 200.

9 Archim. Sofian Boghiu, „Pomenirea Sfintei Cuvioase Parascheva...” (Commemoration of the Venerable

Saint Paraskevi), in vol. Buchet de cuvântări...( Collected speeches), p. 205.

${ }^{10}$ Archim. Sofian Boghiu, Praznicul Schimbării la Faţă (The Feast of the Transfiguration), in vol. Buchet de cuvântări(Collected Speeches)..., p. 127.

${ }^{11}$ Archim. Sofian Boghiu, Pomenirea Sfântului Ioan Evanghelistul (The Commemoration of St John the

Evangelist), in vol. Buchet de cuvântări..., p. 189.

${ }^{12}$ Archim. Sofian Boghiu, Praznicul Schimbării la Faţă..., in vol. Buchet de cuvântări..., 128-129.
} 
"Mount Horeb is known in the Holy Scripture particularly for four events: 1. At the foot of the mountain God showed himself to Moses in the form of the burning bush, not consumed by fire; 2 . It was the rock of this mountain that Moses struck with his rod and God made water come out from the rock for his people; 3. On the top of this mountain Moses stood with his arms raised in the form of a cross, while Joshua Navi fought the Amalekites; 4. In one of the caves in this mountain, God showed himself to the Prophet Elijah, when he had fled from the persecution of King Ahab and Jezebel, who wanted to have him killed"13.

The ending offers, at times, an exhortation towards faith and spiritual perfection, demonstrating the author's wish to indicate the path by which the Christians can attain redemption. Thus, in the ending of the Sermon before the Exaltation of the Holy Cross, we read the following:

\begin{abstract}
"The icons and liturgies of the holy churches await us. The Lord Jesus Christ Himself is summoning us, he who is present in the homes of Christians but especially on the Holy Altars and in the Holy Mysteries. He calls upon us, telling us all and each of us individually: Come to me, all you who are weary and burdened, and I will give you rest» (Matthew 11, 28). Let us listen to His gentle voice and his relentless calling and be worthy of His aid, His kindness, His comfort, His peace, Amen!"14. Also, the Sermon on the Feast of Saint John the Evangelist ends as follows: "The bond between the Savior and us Christians is illustrated by the bond between the vine and its sprouts, or that between the body and the soul. By thoroughly reading the pages filled with grace, light and Godly love, written by Saint John in his Gospel, let us experience great joy. In the end, another exhortation: I give this to you so that you may read it carefully and fulfill, to the best of your powers, the command of love for God and for your fellow people. Because, as the same John says, in the first of his three epistles: "Whoever does not love does not know God, because God is love... If anyone acknowledges that Jesus is the Son of God, God lives in them and they in God» (I John 4, 8,16). Amen"15.
\end{abstract}

In other cases, the father concludes his sermon by an invocation:

"Come, My Lord Jesus, Savior, and ban from us all that is inimical and all that is against us. Comfort our life, Lord, have mercy on us and on the world You have created and redeem our souls as the Kind and Loving Master that you are" comprehension, as you gave Thomas, so that we may know You and believe in You as Thomas did, and we shall call to You from the bottom of our souls «My Lord and God» and by believing, we shall live our life in Your Name, Lord Jesus Christ"17.

On the Divine Providence, On Prayer or Advice to those who confess are titles of meditations or teachings that the father insisted on bequeathing to his disciples and followers, as valuable sources of guidance and advice:

"Confession must be without shame in telling your sin as you have committed it, that is, by revealing it in all its severity. Confess all your bad habits and do not blame one or another,

\footnotetext{
${ }^{13}$ Archim. Sofian Boghiu, Duminica Sfântului Ioan Scărarul(Sunday of Saint John of the Ladder) in vol. Buchet de cuvântări... (Collected Speeches), p. 64.

${ }^{14}$ Archim. Sofian Boghiu , Duminica dinaintea Înălţării Sfintei Cruc (The Sunday before the Exaltation of the Holy Cross), in the vol. Buchet de cuvântări.. (Collected Speeches)., p. 144.

${ }^{15}$ Archim. Sofian Boghiu, Pomenirea Sfântului Ioan Evanghelistul (Commemoration of John the Evangelist), în vol. Buchet de cuvântări..., p. 196.

${ }^{16}$ Archim. Sofian Boghiu, Duminica dinaintea Naşterii Domnului (Sunday before the Birth of the Lord), în vol. Buchet de cuvântări..., p. 175.

${ }^{17}$ Archim. Sofian Boghiu, Duminica Tomii (Thomas' Sunday) (I), în vol. Buchet de cuvântări..., p. 96.
} 
but blame yourself before God and the priest and show to him all the wounds of your $\sin . . ., 18$.

The style is fluent, concise and clear, its main feature being the biblical nature, because each sermon strongly reflects the spirit of the Holy Scripture. By using a homiletic style, abundantly enriched with rhetorical devices, the preacher's penchant for the melodic and sublime voice of words crowned by multiple meanings is revealed; this is meant to warm the hearts of audience. Among these, the most frequent are the epithets: "good man, noble and very gentle", "burning thirst", "the good and merciful Mother of the Lord", "blessed and sacred spring", "healing grace", "unspoken joys", "impaired health", "old and concealed sins", "the meanest and most ardent desires", "unshattered trust", "just as kind and readily helpful", "The mother of us, baptized earthmen", "powerless glance”, "clear mind", "desperate calls", "powerful faith", "fervent prayer", "terrible plight", "persistent and forceful prayer", "lively and endless bond", "more precious gift"; enumeration: "many suffering people of all kinds, men, women and children, some kings and queens, many nobles and commoners, many poor and many rich healed", "troubled by a restless hate, envy, greed", "darkens the mind, shakes the will, petrifies the tenderness of love, smothers good sense", "I have made one or many mistakes, I have eaten or drunk too much, I have committed a crime or a bad deed, I have fostered meanness in my soul towards my fellow men, I have despised the principle of good sense", "special prayers, liturgies and the Holy Mysteries", "fasting and abstinence and prayers", "yesterday, today and forever", "he fell silent, rejected the Apostles and rejected the woman", "her deed, her steady faith, her deep prayer, her sincere, convincing prayer", "confronted by troubles, illness, shortage and suffering"; comparison: "a bigger and more beautiful church than the one built before by Emperor Leon", "their poison flows from the soul into the body just like germs spread in the blood", "guarding ourselves against sin like we guard ourselves against poison or fire", "I honor her as well, as I would a true mother", "desperately, the mother runs", "we shall be aided and comforted just like that poor woman was", "let us pray in faith and with perseverance, like the woman of Canaan prayed"; personification: "with it we can taste the joys of life in a useful way", "his soul is sick", "sin first paralyzes our inner forces", "the soul of that poor mother was torn apart by grief", "her immense grief taught her to pray so fervently", "the answer shall be tardy"; metaphor: "her motherly kindness", "their poison overflows from the soul into the body", "a sun inside the heart", "the Great Unmercenary Doctor who does not accept any pay", "His earthly establishment", "from the bottom of the heart", "the slayer hidden within", "he who knows the hearts", "the spring and reason of our life"; inversion: "her poor daughter", "grief so terrible”, „name so sacred”, ,"heartbreaking grief", "great disdain", "so great her grief".

The plain language, carefully selected, comprehensible to all listeners, is, in fact the liturgical language, the language of the believers, of the church books and of the Holy Scripture. It particularly avoids neologisms and foreign words, the sentences are short and the author does not entangle himself in lengthy arguments. When evoking sins, certain failures or the effort to rise again, he always counts himself among the sinners, preaching humbly, placing himself within the issues and not from a distance or with reprimand.

He speaks as a simple man, aware of his own sins and weaknesses, not just as priest and preacher who, by nature of his mission, must often have an impressive appearance..

\footnotetext{
${ }^{18}$ Archim. Sofian Boghiu, Sfătuire către cei ce se spovedesc (Advise to those who confess), în vol. Buchet de cuvântări..., p. 269.
} 
Thus, together with the substantial messages, his simplicity and humbleness constitute characteristic features of the sermons included in the volume mentioned above.

\section{CONCLISIONS}

The purpose of the speeches of father Sofian Boghiu is to enlighten and set the soul free, in other words, to heal those who have fallen victims to sin, attracting them towards the Church of Christ, because "here, we mystically encounter our Savior, the Mother of Our Lord, all the Celestial Forces, the Holy Apostles and all His friends, prophets, confessors, hierarchs, pious men, because the friends of God are certain Saints, who have not strayed from His Holy Commandments"19. We must remark the persuasive force of his speeches, relying on the text of the Scripture and giving powerful examples of preaching in the teachings of the Gospel of our Savior, Jesus Christ, not in an abstract form but in a very concrete manner, related to the realities of the Christians' lives and their religious and moral aspirations.

\section{BIBLIOGRAPHY}

[1] † Daniel, Patriarch of the Romanian Orthodox Church, „Cuvânt inainte” (Foreword), in Un iconar de suflete - Părintele Sofian Boghiu (A painter of souls - Father Sofian Boghiu), Archim. Mihail Stanciu and Protos. Veniamin Goreanu (eds.), Basilica Publishing House of the Romanian Patriarchate, Bucharest, 2009,

[2] †Teoctist, ,Precuvântare” (Preliminary Speech), to Arhim. Sofian Boghiu, Buchet de cuvântări. Predici şi meditaţii (Collected Speeches. Sermons and meditations), EIBMBOR, Bucharest, 2006,

[3] Arhim. Ioanichie Bălan, Convorbiri duhovniceşti (Spiritual Conversations), vol. I, Editura Episcopiei Romanului şi Huşilor, 1993,

[4] Protos. Veniamin Goreanu, “,Vrednicul slujitor al lui Hristos, părintele arhimandrit Sofian Boghiu (The worthy servant of Christ, father archimandrite Sofian Boghiu (1912-2002)", in vol. Un iconar de suflete - Părintele Sofian Boghiu (A painter of souls - Father Sofian Boghiu), Archim. Mihail Stanciu and protos. dr. Veniamin Goreanu (eds.), Basilica Publishing House, Bucharest, 2009

\footnotetext{
${ }^{19}$ Archim. Sofian Boghiu, Duminica lui Zaheu (Zacchaeus' Sunday), in vol. Buchet de cuvântări.. (Collected of speeches)., p. 33.
} 